\title{
Morphology of sternum in patients with Scheuermann's kyphosis: is it different from that of healthy adolescents?
}

\author{
Xu Sun, Zhou Wang, Zhonghui Chen, Xi Chen, Zezhang Zhu, Yong Qiu*, Feng Zhu, Bangping Qian \\ From The 10th Meeting of the International Research Society of Spinal Deformities (IRSSD 2014 Sapporo) \\ Sapporo, Japan. 29 June - 2 July 2014
}

\section{Objective}

To investigate the morphological characteristics of sternum in patients with Scheuermann's disease (SD) and to explore the role of sternum growth in the pathogenesis of SD kyphosis.

\section{Methods}

20 SD patients with thoracic kyphosis aged 10 to 18 years were included in this study. 30 healthy volunteers were recruited to serve as controls. Computed tomography 3D reconstruction of the total sternum in supine position was performed. The length, width, thickness of manubrium and mesosternum was measured respectively. Meanwhile, the angle $(\alpha)$ between the axis of manubrium and that of mesosternum were also measured. The size of sternum and angle $\alpha$ were compared between SD patients and normal controls using the Studenst test.

\section{Results}

No significant differences were found between SD patients and normal controls in terms of age and gender $(\mathrm{P}>0.05)$. The length, width, thickness of the manubrium was $4.7 \pm 0.8 \mathrm{~cm}, 5.5 \pm 0.6 \mathrm{~cm}, 0.9 \pm 0.1 \mathrm{~cm}$ and of mesosternum was $11.4 \pm 1.1 \mathrm{~cm}, 2.5 \pm 0.3 \mathrm{~cm}, 1.2 \pm 0.1 \mathrm{~cm}$ in $S D$ patients, respectively. In normal controls, the length, width, thickness of the manubrium was $4.5 \pm 0.7 \mathrm{~cm}, 5.5 \pm 0.3 \mathrm{~cm}$, $0.9 \pm 0.1 \mathrm{~cm}$ and of mesosternum was $10.7 \pm 1.2 \mathrm{~cm}$, $2.6 \pm 0.3 \mathrm{~cm}, 1.0 \pm 0.2 \mathrm{~cm}$, respectively. The length, thickness of mesosternum were significantly smaller in SD patients than that in healthy controls $(\mathrm{P}=0.02)$. The angle $\alpha$ was significantly larger in SD patients than that in controls $\left(34 \pm 5^{\circ}\right.$ versus $\left.28 \pm 2^{\circ}, \mathrm{P}=0.01\right)$.

\footnotetext{
Spine Surgery, Affiliated Drum Tower Hospital of Nanjing University Medical
} School, Nanjing 210008, China

(c) 2015 Sun et al; licensee BioMed Central Ltd. This is an Open Access article distributed under the terms of the Creative Commons Attribution License (http://creativecommons.org/licenses/by/4.0), which permits unrestricted use, distribution, and reproduction in any medium, provided the original work is properly cited. The Creative Commons Public Domain Dedication waiver (http:// creativecommons.org/publicdomain/zero/1.0/) applies to the data made available in this article, unless otherwise stated.

\section{and take full advantage of:}

- Convenient online submission

- Thorough peer review

- No space constraints or color figure charges

- Research which is freely available for redistribution

Submit your manuscript at Submit your manuscript at C BioMed Central
- Immediate publication on acceptance

- Inclusion in PubMed, CAS, Scopus and Google Scholar

\section{BiolMed Central}

\section{Conclusion}

Probably the smaller length of sternum and abnormal the compressive forces on the vertebral endplates anteriorly, which might be involved in the pathogenesis of Cite this article as: Sun et al:: Morphology of sternum in patients with Scheuermann's kyphosis: is it different from that of healthy adolescents? Scoliosis 2015 10(Suppl 1):P15. articulation of manubrium and mesosternum increases 